\title{
SLOVAK EXPERIENCE AFTER 10 YEARS FROM THE INTRODUCTION OF THE EURO AS GLOBALIZATION FACTOR
}

\author{
Zoltan Seben ${ }^{1, *}$, Enikö Korcsmaros ${ }^{2}$, Renata Machova ${ }^{3}$ and Lilla Feher ${ }^{4}$ \\ ${ }^{1}$ J. Selye University, Faculty of Economics, Bratislavská street 3322, Komárno, Slovakia \\ ${ }^{2}$ J. Selye University, Faculty of Economics, Bratislavská street 3322, Komárno, Slovakia \\ ${ }^{3}$ J. Selye University, Faculty of Economics, Bratislavská street 3322, Komárno, Slovakia \\ ${ }^{4}$ J. Selye University, Faculty of Economics, Bratislavská street 3322, Komárno, Slovakia
}

\begin{abstract}
One of Slovakia's globalization tendencies is the successful introduction of the Eurocurrency. It has been 10 years since the introduction of the euro in Slovakia. It is a sufficient time for us to continuously assess the real situation and attitudes of the citizens in this area. There are several publicly available studies, research findings conducted by Eurobarometer, Fincenter or the National bank, which focus on advantages and disadvantages of the euro currency. The most frequently mentioned advantages are price stability, transaction cost decrease in foreign trade and tourism, Slovak export increase and the removal of exchange rate risk. On the other side, Slovakia has lost its independent monetary policy and the member country is also expected to participate in the euro area rescue mechanism. Similarly the research team of the Faculty of Economics of J. Selye University was invited by Hungarian Pallas Athene Domus Educationis Foundation to participate in the research project named ten years of euro - Slovak experience. Based on this project initiative, the aim of the paper is to find out the experience regarding the euro among citizens, also with an emphasis on cross-border activity. In order to achieve the research objectives we applied primary data collection to obtain information about the researched issue. An anonymous questionnaire survey was conducted among the respondents. Data collection among the residents was realized with a help of an agent, but also an online questionnaire was provided for the respondents in 2018. Statistic indicators were used to verify our assumptions.
\end{abstract}

\section{Introduction}

Slovakia as one of ten Central and Eastern European countries became a member state of the European Union on May 1, 2004. Slovakia entered the exchange rate mechanism ERM II shortly after becoming a member state of the European Union, and adopted the euro currency in 2009. Ten years ago, on the first day of January people gave up their Slovak crowns and adopted a new currency. 10 years from the introduction of euro, it is

\footnotetext{
*Corresponding author: sebenz@ujs.sk
} 
sufficient time to make assessments about the attitudes of the citizens. These outputs are valuable not only for the country, but for the wider globalised areas too. The authors of the paper, as members of research team were invited by Hungarian Pallas Athene Domus Educationis Foundation to participate in a specific project, which is aimed to collect the Slovakian experience about euro as currency, tool for making payments. This paper contains important findings of our research.

\section{Theoretical background}

Theoretical base is given by the official website of the European Union, where the euro as the official currency for 19 member countries is characterized in the section called about the EU. On this website, we can also find a number of reports, studies, official documents and statistics in the documents section, which deal broadly with the issue of the euro. Another source of information is the official website of the European Central Bank. On this website we can find information about the monetary policy, euro and published research outputs and statistics are also useful. Similarly National bank of Slovakia has its own official webpage $[1,2,3]$.

On the other hand, there are different studies, which explore the issue of the euro from different globalisation perspectives.

In the paper concentrated on comparison of selected methods for performance evaluation of Czech and Slovak commercial banks the authors stated ,the advantage of multi-criteria methods as there is no limitation how many criteria could be evaluated. This method could be also used to set up the most performed banks, or bank branches, but also to find the most suitable bank products"[4]. In another study about economic sustainability in a wider context, the authors described, the relationship between the variables of the national average monthly wage and ICT services employment. The results suggested strong correlation, statistically significant relationship between these two variables"[5]. The questionnaire research done by authors on ,,consumer perceptions of private label products showed the price as the most important factor in purchasing private label products. The researchers focused on the change in preferences of purchased products considering gender, age, education, income, and consumer status of respondents"[6]. One of the first papers which, investigate the link between corporate governance and gender equality in companies on the Bratislava Stock Exchange is named gender equality and corporate governance in Slovakia. Authors in their paper confirmed the correlation between the representation of women on the boards and the level of corporate governance in companies listed on the Bratislava Stock Exchange"[7]. Another research findings from the period 2010-2016 used samples from the V4 countries are demonstrated in the paper with the theme, an in-depth analysis of the summary innovation index in the V4 countries. Slovakia belongs to the moderate innovators, the performance of Slovakia increased by $8 \%$ relative to that of the EU in 2010“[8]. The paradigms of European ,integration process in the Visegrád group and its essence consider other authors as too simplistic to define only as consolidation of the efforts of Central European countries in order to return to Europe through Euro-Atlantic integration"[9]. A broad spectrum research area with the impact on our topic are behavioural aspects of the financial decision-making. This type of study can be perceived as a stimulus for further research into to use of fuzzy logic in finance, financial management and decision making"[10]. Actual paper deals with the macroeconomic indicators of EU members Estonia, Latvia, Lithuania, Slovakia and Slovenia, which are compared with Polish. Authors chose the period 2005-2017 and reflected economic changes, that took place in these countries after joining the Eurozone [11]. An empirical analysis based on annual Euro area data for the period 1995-2016 was conducted by two researchers and they confirmed strong export specialization in Slovakia 
too [12]. A strong conclusion can be read in the article about economic and political factors affecting attitudes of Slovakia towards the future of the EU, the author is in favour of the idea, that Slovakia's Eurozone membership is important to enhance its cooperation within the EU [13]. In another study about euro in Slovakia the author's point of view is, that Euro adoption did not make Slovakia more vulnerable to the pan-European problems [14]. For member states wishing to adopt the euro, there is an another recommendation to start with an examination of the domestic political situation, pro/anti European stances [15].

\section{Research methodology and results}

In order to achieve the research outputs, an anonymous questionnaire survey was conducted among the respondents. The research team created a questionnaire consisting of 23 questions. The questionnaire was divided into three parts, the first covered basic information on respondents (gender, age, education, place of living, marital status, profession), the second part consisted of questions with choice of answers on a given Likert scale from one to five, and the third part were open and other questions. We applied primary data collection to obtain information about the researched issue. Data collection among the residents was realized with a help of an agent and online questionnaire in time interval of December, 2018. 218 completed questionnaires served as a basic for data collection. In order to analyse the collected data we applied statistical methods and distribution. The following part of the paper presents the strategic survey results through six selected questions.

Question 1: I perceive the introduction of the euro in Slovakia positively

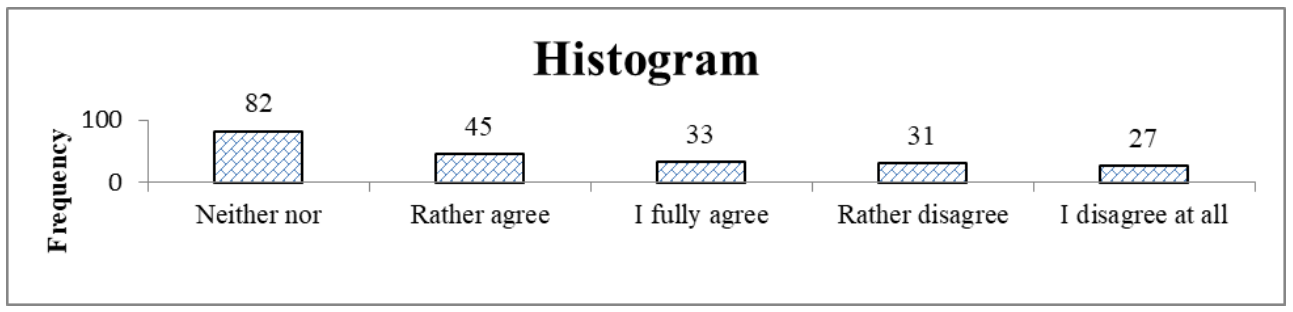

The scale: I disagree at all=1, Rather disagree=2, Neither nor=3, Rather agree=4, I fully agree $=5$

\begin{tabular}{|c|c|c|c|}
\hline \multicolumn{4}{|c|}{ Statistics } \\
\hline Mode & Median & Skewness & Kurtosis \\
\hline 3 & 3 & $-0,1341$ & $-0,6773$ \\
\hline
\end{tabular}

Right-sided asymmetry, flatter distribution

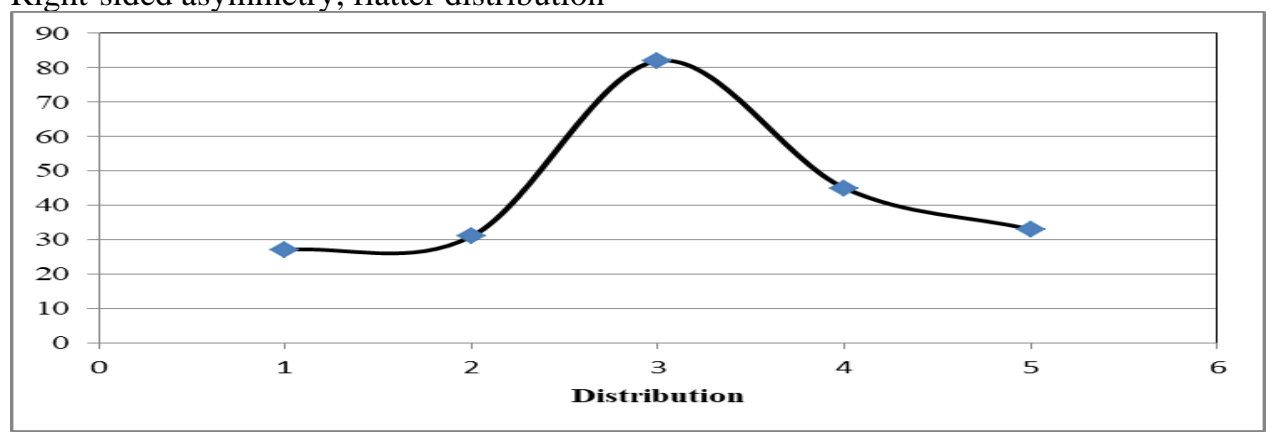

Fig. 1. Histogram and distribution for question 1 
The structure of responses can be characterized as right-sided asymetry of flatter distribution. The most common value in the responses is 3 . According to histogram there is a very positive perception of the introduction of the euro in Slovakia.

Question 2: The advantage of the introduction of the euro is the simplification of foreign trade

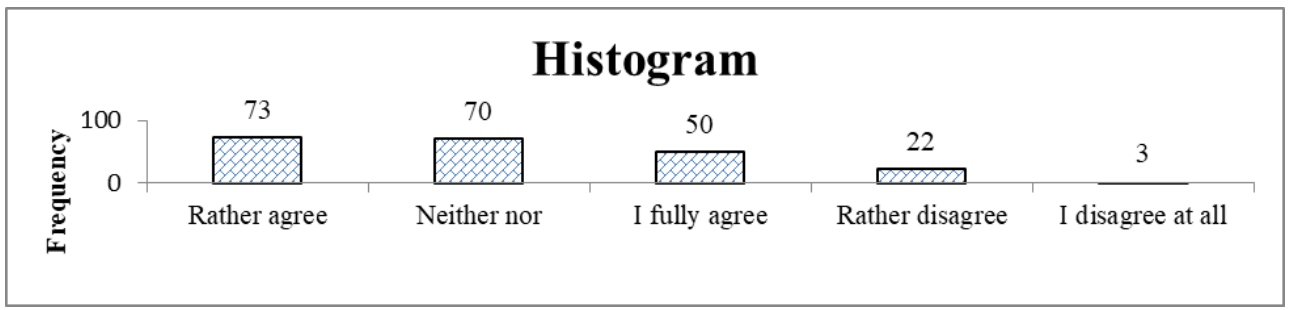

The scale: I disagree at all=1, Rather disagree=2, Neither nor=3, Rather agree=4, I fully agree $=5$

\begin{tabular}{|c|c|c|c|}
\hline \multicolumn{4}{|c|}{ Statistics } \\
\hline Mode & Median & Skewness & Kurtosis \\
\hline 4 & 4 & $-0,2706$ & $-0,5584$ \\
\hline
\end{tabular}

Right-sided asymmetry, flatter distribution

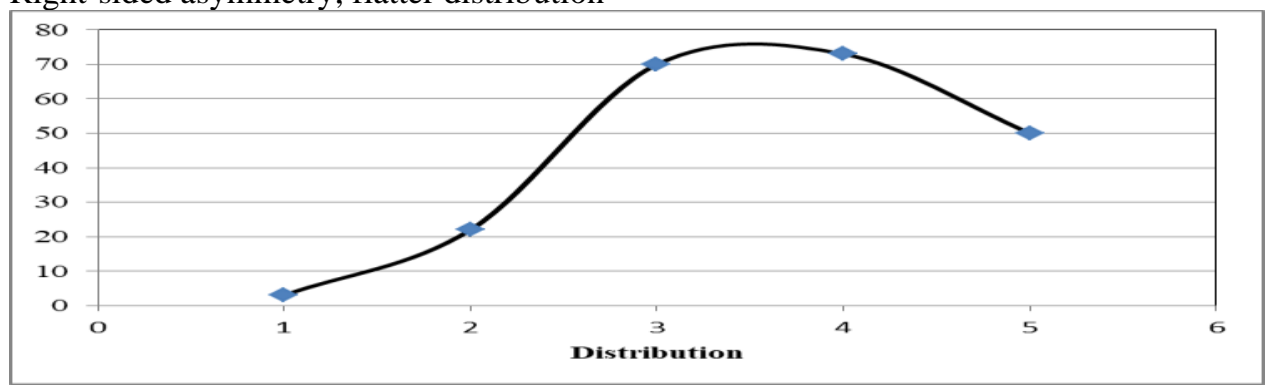

Fig. 2. Histogram and distribution for question 2

The structure of responses can be characterized as right-sided asymetry of flatter distribution. The most common value in the responses is 4. According to histogram the most answers are at the right side of the distribution. The simplification of foreign trade due to euro is recognized as advantage by the most of respondents.

Question 3: The advantage of the introduction of the euro is a stronger, more stable currency

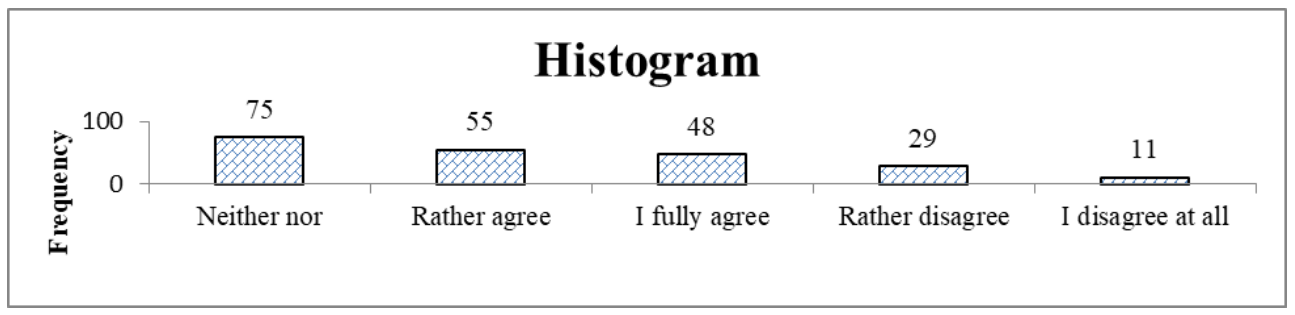

The scale: I disagree at all=1, Rather disagree=2, Neither nor=3, Rather agree=4, I fully agree $=5$ 


\begin{tabular}{|c|c|c|c|}
\hline \multicolumn{4}{|c|}{ Statistics } \\
\hline Mode & Median & Skewness & Kurtosis \\
\hline 3 & 3 & $-0,2448$ & $-0,6252$ \\
\hline
\end{tabular}

Right-sided asymmetry, flatter distribution

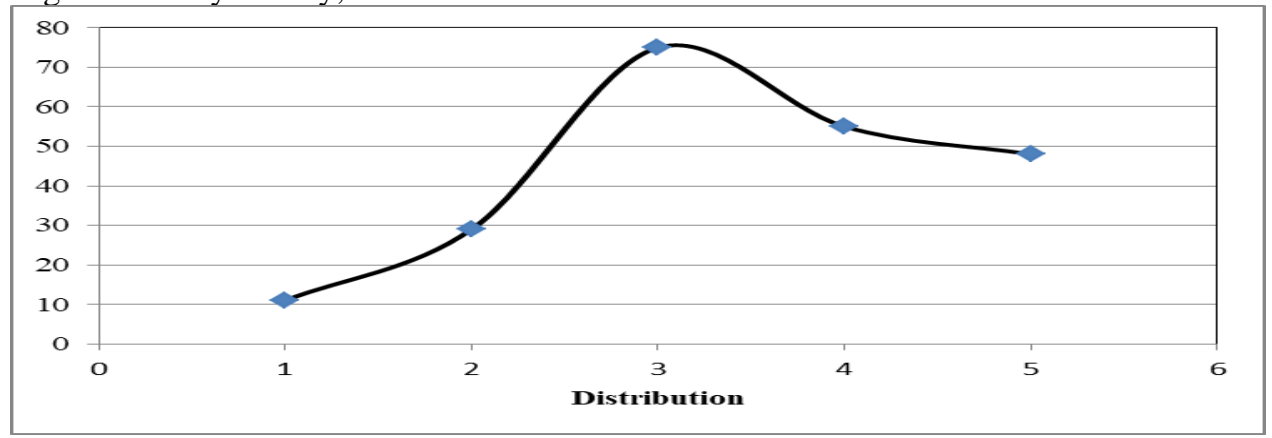

Fig. 3. Histogram and distribution for question 3

The structure of responses can be characterized as right-sided asymetry of flatter distribution. The most common value in the responses is 3. Although most responses are on scale value of three, the vast majority of respondents agree that the advantage of introduction of euro is stronger, more stable currency.

Question 4: The advantage of adopting the euro is that it is easier to compare prices for products and services within the euro area

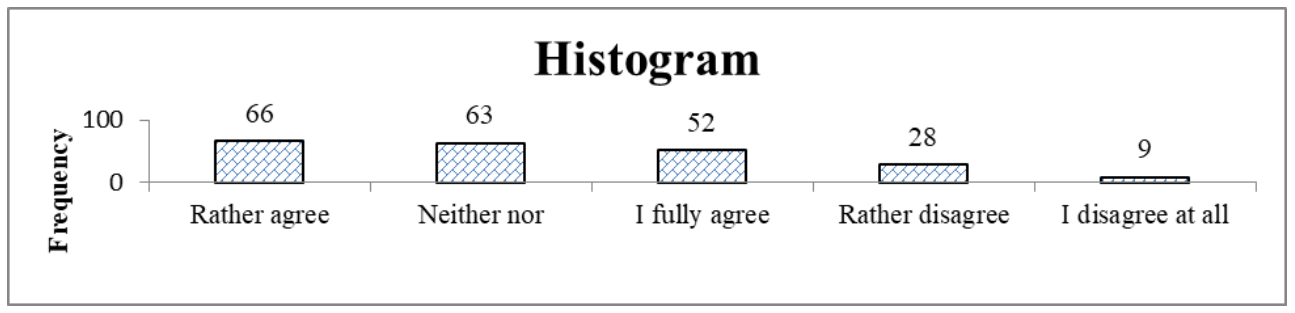

The scale: I disagree at all=1, Rather disagree=2, Neither nor=3, Rather agree $=4$, I fully agree $=5$

\begin{tabular}{|c|c|c|c|}
\hline \multicolumn{4}{|c|}{ Statistics } \\
\hline Mode & Median & Skewness & Kurtosis \\
\hline 4 & 4 & $-0,383$ & $-0,5811$ \\
\hline
\end{tabular}

Right-sided asymmetry, flatter distribution

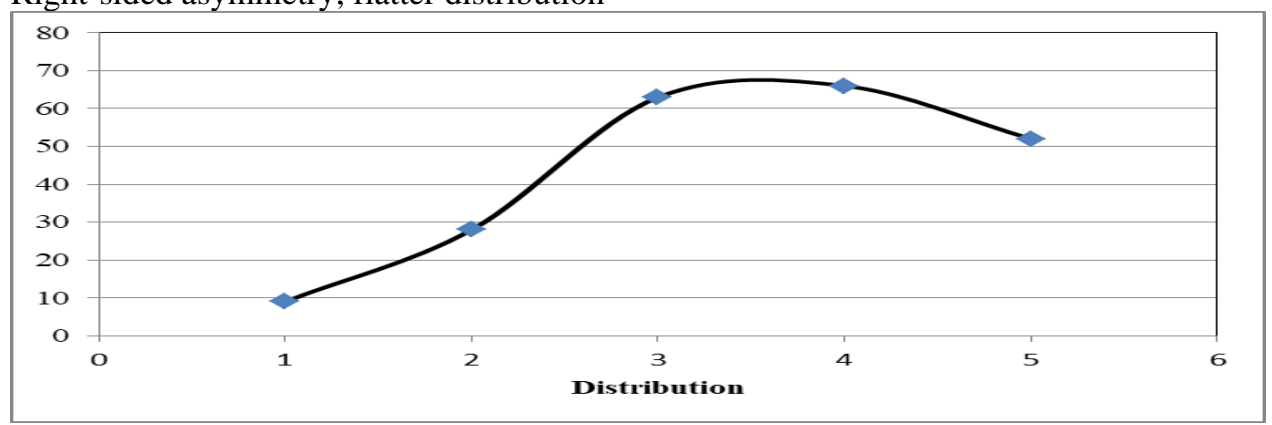

Fig. 4. Histogram and distribution for question 4 
The structure of responses can be characterized as right-sided asymetry of flatter distribution. The most common value in the responses is 4 . This question has its practical aspect through cross-border activity, most respondents make systematic purchases in Hungary, so they know, what are the difficulties, because Hungary is not a part of euro area.

Question 5: The disadvantage of the introduction of the euro is its negative impact on the standard of living

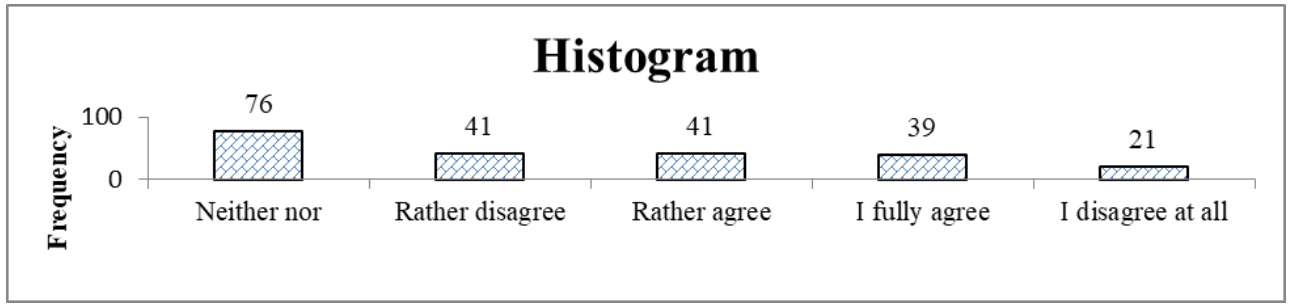

The scale: I disagree at all=1, Rather disagree=2, Neither nor=3, Rather agree=4, I fully agree $=5$

\begin{tabular}{|c|c|c|c|}
\hline \multicolumn{4}{|c|}{ Statistics } \\
\hline Mode & Median & Skewness & Kurtosis \\
\hline 3 & 3 & $-0,034$ & $-0,801$ \\
\hline
\end{tabular}

Right-sided asymmetry, flatter distribution

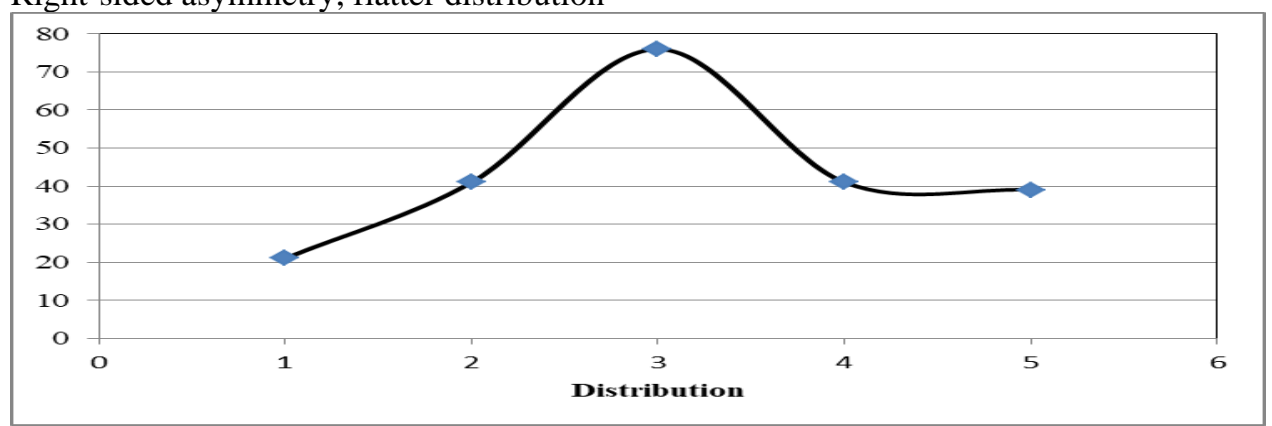

Fig. 5. Histogram and distribution for question 5

The structure of responses can be characterized as right-sided asymetry of flatter distribution. The most common value in the responses is 3 . As can be seen in the histogram, there are more respondents in the group who agree with the statement than in the group who disagree. The standard of living includes many factors and is closely related to quality of life. Responses show a slight dissatisfaction with the standard of living.

Question 6: The disadvantage of the euro is the numerous existence of one and two cents, which we consider worthless

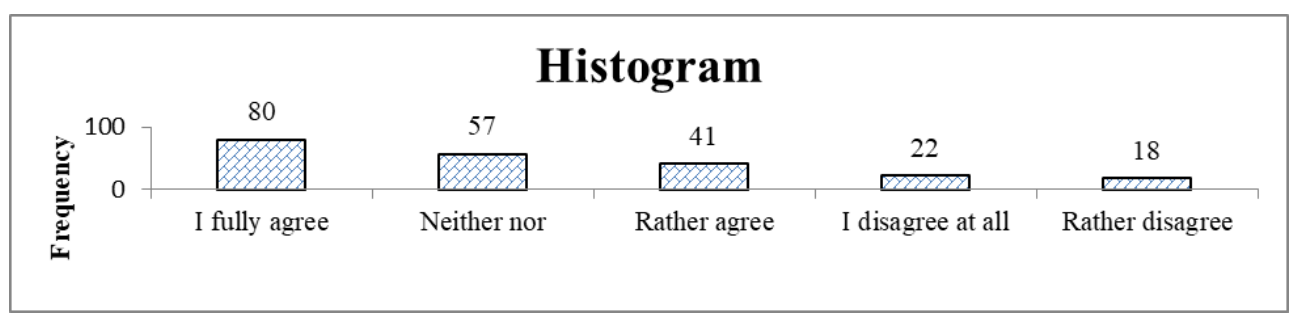


The scale: I disagree at all=1, Rather disagree=2, Neither nor=3, Rather agree=4, I fully agree $=5$

\begin{tabular}{|c|c|c|c|}
\hline \multicolumn{4}{|c|}{ Statistics } \\
\hline Mode & Median & Skewness & Kurtosis \\
\hline 5 & 4 & $-0,5867$ & $-0,7352$ \\
\hline
\end{tabular}

Right-sided asymmetry, flatter distribution

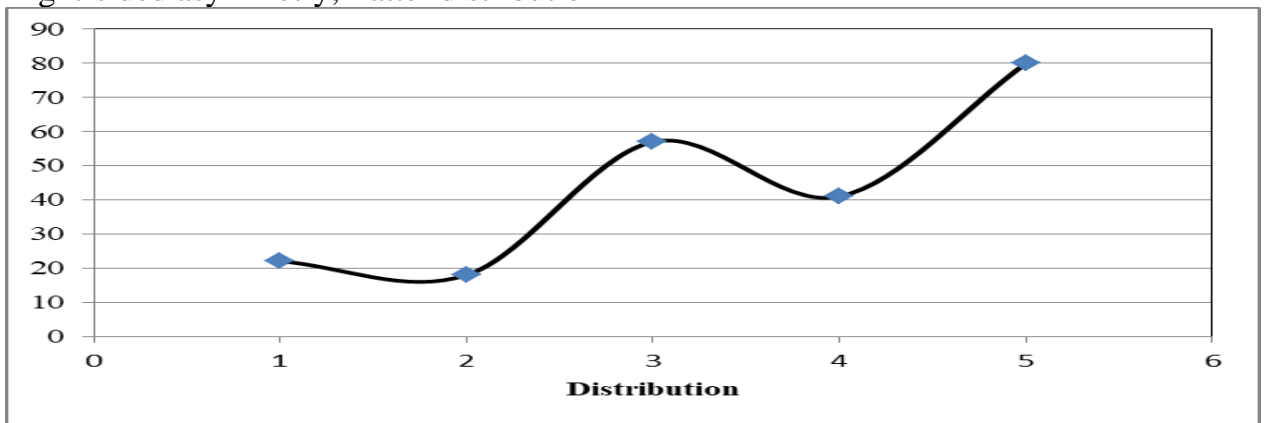

Fig. 6. Histogram and distribution for question 6

The structure of responses can be characterized as right-sided asymetry of flatter distribution. The most common value in the responses is 5. Respondents largely agreed with the statement, that the disadvantage of the euro is the numerous existence of one and two cents, which are considered worthless. It is a very practical question too and the European Commission has been dealing with this issue since 2012. Some states as Finland, Belgium or Netherlands stopped minting these cent coins.

In the final part of this chapter we use the correlation matrix to show the correlation coefficients between the answers on the questions.

Table 1. Correlation matrix

\begin{tabular}{|c|c|c|c|c|c|c|}
\hline & $\begin{array}{l}\text { Question } \\
1\end{array}$ & $\begin{array}{l}\text { Question } \\
2\end{array}$ & $\begin{array}{l}\text { Question } \\
3\end{array}$ & $\begin{array}{l}\text { Question } \\
4\end{array}$ & $\begin{array}{l}\text { Question } \\
5\end{array}$ & $\begin{array}{l}\text { Question } \\
6\end{array}$ \\
\hline Question 1 & 1 & 0,39 & 0,58 & 0,23 & $-0,29$ & 0,09 \\
\hline Question 2 & 0,39 & 1 & 0,44 & 0,39 & 0,008 & 0,21 \\
\hline Question 3 & 0,58 & 0,44 & 1 & 0,29 & $-0,23$ & 0,11 \\
\hline Question 4 & 0,23 & 0,39 & 0,29 & 1 & 0,08 & 0,16 \\
\hline Question 5 & $-0,29$ & 0,008 & $-0,23$ & 0,08 & 1 & 0,16 \\
\hline Question 6 & 0,09 & 0,21 & 0,11 & 0,16 & 0,16 & 1 \\
\hline
\end{tabular}

The results show, that there are much more positive relationships with positive correlation, only two cases are characterized by negative correlation coefficient. The strongest positive relationship is between the answers to the first and third question.

\section{Conclusions}

The euro has been part of our daily lives for ten years. During that time, we have become accustomed to make payments with this currency, although we are faced with some difficulties. According to our research we can confirm, that there is a positive perception of the introduction of the euro. The open question is whether Slovakia from the V4 countries will remain the only one with the euro or not. Furthermore, is ten years a sufficient period for evaluation, moreover this period was marked by the crisis. And what amounts are 
expenditures on housing, water, electricity, gas, food, soft drinks compared to other V4 countries in recent years. These issues will be good bases for our future research intention.

Research behind this paper was supported by the Hungarian Pallas Athene Domus Educationis Foundation within the project PADE - 0117/4

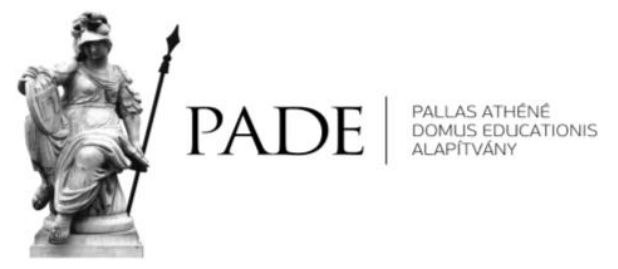

\section{References}

1. Official website of the European Union

2. Official website of the European Central Bank

3. Official website of the National bank of Slovakia

4. B. Gavurova, J. Belas, K. Kocisova, T. Kliestik, Comparison of selected methods for performance evaluation of czech ans slovak commercial banks. Journal of Business Economics and Management, 18, 5 (2017)

5. E. Matudova, T. Corejova, M. Valica, Economic Sustainability in a Wider Context: Case Study of Considerable ICT Sector Sub-Divisions. Sustainability, 10, 7 (2018)

6. K. Valaskova, J. Kliestikova, A. Krizanova, Consumer perceptions of private label products: an empirical astudy. Journal of Competetiveness, 10, 3 (2018)

7. H. Musa, L. Debnarova, Z. Musova, P. Kristofik, Gender equality and corporate governance in slovakia. E\&M Ekonomie a management, 20, 1 (2017)

8. K. Janoskova, P. Kral, An in-depth analysis of the summary innovation index in the $\mathrm{v} 4$ countries. Journal of competitiveness, 11, 2 (2019)

9. S. Rostetska, S. Naumkina, Paradigms of european integration processes in the eu, visegrad group, and ukraine. Baltic Journal of Economic Studies, 5, 3 (2019)

10. K. Valaskova, V. Bartosova, P. Kubala, Behavioural Aspects of the Financial Decision-Making. Organizacija, 52, 1 (2019)

11. J. Heller, R. Warzala, The effects of entering the eurozone on other central and eastern european countries in relation to poland. Journal of competitiveness, 11, 1 (2019)

12. I. Konstantakopoulou, M. G. Tsionas, Measuring comparative advantages in the Euro area. Economic modelling, 76, 260-269 (2019)

13. M. Kurucz, Economic and political factors affecting attitudes of Slovakia and Hungary towards the future of the EU. Economic Annals-XXI, 172, 28-31 (2018)

14. A. Kliber, P. Pluciennik, Euro or not? Vulnerability of Czech and Slovak economies to regional and international turmoil. Economic Modelling, 60, 313-323 (2017)

15. A. Dandashly, A. Verdun, Euro adoption in the Czech Republic, Hungary, and Poland: Laggards by default and laggards by choice. Comparative European Politics, 16, 3 (2018) 